KRZYSZTOF J. SZMIDT

\title{
Pedagogika pozytywna: twórczość - zdolności - mądrość zespolone
}

\section{Wstęp}

Polska pedagogika akademicka wydaje się być jak typowy dziennik telewizyjny - skoncentrowana na niedomaganiach, nieszczęściu, braku. Już pobieżna analiza tematów i przedmiotu badań dysertacji doktorskich i prac habilitacyjnych nie tylko pedagogiki specjalnej i pedagogiki rewalidacyjnej wyraźnie wskazuje, iż główny nurt współczesnej pedagogiki polskiej ogniskuje się na zagadnieniach niedostatku, choroby, dysfunkcji i zaburzeń - deficytu. Ten nurt pedagogiki określam umownie jako pedagogika braku lub niedostatku. Do podstawowych problemów teoretycznych i empirycznych tego nurtu badań należą:

- niepełnosprawność, wszelkiego rodzaju zaburzenia fizyczne i umysłowe;

- niedostosowanie społeczne i zachowania patologiczne dzieci, młodzieży i dorosłych;

- przemoc, agresja, brutalizacja w grupach formalnych i nieformalnych;

- bezrobocie, bezdomność, uwiąd więzi społecznych, marginalizacja i wykluczenie;

- uzależnienia we wszystkich jego rodzajach, od substancji chemicznych po gry komputerowe;

- opresja, przemoc symboliczna, totalitaryzm kulturowy szkoły, domu dziecka, domu kultury, ośrodka wychowawczego, zakładu karnego;

- nierówności, niesprawiedliwość społeczna, kryzys wartości i kryzys wspólnoty;

- negatywny wpływ kultury masowej i mediów na rozwój umysłowy dzieci i młodzieży;

- rodzina jako środowisko przemocy fizycznej i symbolicznej;

- płeć jako czynnik wykluczenia społecznego i kulturowego; 
- nauczyciele i pedagodzy jako manipulatorzy, szkodnicy i realizatorzy opresyjnej polityki edukacyjnej państwa i klas dominujących.

Zaiste, tematy te można by mnożyć. Wyjściową tezą tego tekstu, jak i całej książki Zasoby twórcze człowieka, jest twierdzenie, w myśl którego polska pedagogika akademicka przypomina stan psychologii zachodniej w momencie pojawienia się postulatów psychologii pozytywnej na przełomie XX i XXI w. Podobnie jak tamta, pedagogika w głównym nurcie zajęta jest głównie chorobą, a nie zdrowiem i rozwojem. Ten nurt badań pedagogicznych, zwracających baczniejszą uwagę na zasoby człowieka, jego zdolności i uzdolnienia, twórczość i mądrość życiową, na których można i trzeba budować programy wychowania, nazywam pedagogiką rozwoju lub wzrostu. Łatwo zauważyć, iż sięgam tu po znaną już metaforę Abrahama Maslowa (1990), wykorzystaną w słynnej klasyfikacji potrzeb ludzkich.

\section{Inspiracje - psychologia pozytywna}

Źródłem inspiracji dla pedagogiki rozwoju mogą być tradycyjne koncepcje filozoficzne dotyczące dobrego życia, szczęścia lub mądrości. Ale współczesna pedagogika rozwoju może sięgnąć nieco bliżej - do dynamicznie rozwijającego się kierunku psychologii - psychologii pozytywnej, która tworzy nową jakość $\mathrm{w}$ rodzinie subdyscyplin nauk o człowieku.

Psychologia pozytywna zna dokładnie datę swoich narodzin: jest to rok 1998, kiedy to Martin Seligman, wówczas prezydent Amerykańskiego Towarzystwa Psychologicznego (APA), wezwał członków APA do „reorientacji psychologii z ludzkich słabości na ludzką siłę" (Trzebińska, 2008, s. 21). Sądzi się, iż psychologia pozytywna i jej główne postulaty pojawiły się jako protest wobec psychologii negatywnej, która dominowała przez cały wiek XX, oraz jako reakcja na „epidemię depresji" wśród młodych ludzi w krajach zachodnich, zwiększającą się liczbę rozwodów, samobójstw, przestępstw przeciwko zdrowiu i życiu oraz zanik więzi społecznych (Czapiński, 2004, s. 7). Podkreśla się (Seligman, 2002; Czapiński, 2004; Trzebińska, 2008), że w całej dotychczasowej historii psychologii przeważała tematyka negatywna: agresja i uprzedzenia, zaburzenia i choroby psychiczne, negatywne emocje i zachowania. Jak twierdzi Janusz Czapiński (2004, s. 8), analiza zawartości 172 podręczników psychologii wydanych w latach 1875-1961 wykazała ponad dwukrotną przewagę terminów odnoszących się do emocji negatywnych nad pojęciami określającymi emocje pozytywne. W polskich publikacjach psychologicznych, wydanych w latach 1946-1981 terminy negatywne dwukrotnie przeważają nad terminami pozytywnymi. Co ciekawe i bardzo znamienne, w ciągu ostatnich 20 lat XX w. w literaturze psychologicznej pojawiało się 46000 artykułów o depresji, a tylko 400 artykułów o radości (Seligman, 2004, s. 19). 
Współtwórca psychologii pozytywnej, Martin Seligman (2004, s. 19), pyta: „Jak to się stało, że nauki społeczne zaczęły uważać ludzkie zalety - odwagę, altruizm, uczciwość, wiarę, obowiązkowość, odpowiedzialność, dobre usposobienie, wytrwałość - za zachowania uboczne, za złudzenia i za obrony, podczas gdy ludzkie słabości - chciwość, lęk, żądza, egoizm, strach, gniew, depresja - są uważane za autentyczne? Dlaczego mocne i słabe strony człowieka nie są symetryczne pod względem swej autentyczności?" I odpowiada, że współczesna psychologia była dotąd zaabsorbowana negatywną stroną życia, a zachowania człowieka interpretowała w kategoriach modelu choroby. „Jej głównym sposobem interweniowania było naprawianie szkody. Pod względem teoretycznym do niedawna była ona wiktymologią (nauką o ofiarach i poszkodowanych)" (tamże, s. 20). Ten stan rzeczy ma zmienić nowa psychologia pozytywna.

Głównym przedmiotem zainteresowań psychologii pozytywnej jest dobre życie, a celem badań jest opisanie i wyjaśnienie, na czym z psychologicznego punktu widzenia polega dobre życie i jakie czynniki do niego prowadzą (Trzebińska, 2008, s. 9). Psychologia pozytywna (tamże, s. 9-11) zwraca uwagę przede wszystkim na fakt, iż ludzie są twórczy, produktywni, z powodzeniem radzą sobie z trudnościami i wychodzą z opresji życiowych oraz cieszą się życiem. Badacze reprezentujący ten nurt koncentrują uwagę na tych przesłankach dobrego życia - zasobach - które można zaliczyć do trwałego wyposażenia psychicznego człowieka, a nie na tych, które są chwilowe, migawkowe, albo tkwią poza jednostką. Dla pedagogów twórczości i pedagogów społecznych ważny jest jeden z głównych problemów psychologii pozytywnej, który dotyka koncepcji rozwoju i wychowania Heleny Radlińskiej: poszukiwanie odpowiedzi na pytanie, „na czym w sobie samym człowiek może polegać przy rozwiązywaniu swoich życiowych zadań" (tamże, s. 10). Pytanie to odnosimy do kategorii sił jednostkowych, zasobów twórczych jednostki, jej zdolności i wartości będących podstawą pomyślnego rozwoju.

Większość z postulatów i przyjętych w badaniach psychologów pozytywnych zasad ogólnych pośrednio lub bezpośrednio odnosi się do zasobów twórczych, zdrowia i dobrostanu człowieka, jego potencjalnych i urzeczywistnionych zdolności i uzdolnień, cnót obywatelskich i osobistych (zob. Carr, 2009; Czapiński, red., 2004; Diener i Biswas-Diener, 2011; Fredrickson, 2011; Seligman, 2004; 2005; 2011; Trzebińska, 2008; Wiseman, 2012). A zatem dotyczy czynników niezmiernie ważnych dla pedagogiki, jej przedmiotu badań i celów jako subdyscypliny naukowej. Rzecz jasna, pedagogiki, która nie koncentruje się wyłącznie na dysfunkcjach i brakach, którą określamy tu jako pedagogika rozwoju.

Z podstawowych twierdzeń psychologii pozytywnej dla przyszłej pedagogiki rozwoju wynikają określone postulaty do przyszłych badań.

\section{Po pierwsze, twórczość}

Twórczość i jej wymiar personalny - kreatywność stały się w ostatnich latach tematem modnym w pedagogice, która - jak można przypuszczać - pospiesznie 
kompensuje lata zaniedbań i niedostrzegania tej tematyki (Beghetto i Kaufman, eds, 2010; Kaufman i Beghetto, 2009; Starko, fourth ed. 2010, Piirto 2011; Karwowski i Gajda, red., 2010; Szmidt, 2012; Uszyńska-Jarmoc, 2007). Zwiększa się liczba badań nad twórczością wychowanków i wychowawców, rodzą się i rozwijają nowe koncepcje kreatywności, pomocy uczniom w tworzeniu szkoły wspierającej twórczość i czynników mających pozytywny lub negatywny wpływ na efekty działań twórczych.

Twórczość rozumiana szeroko i egalitarnie jako aktywność lub postawa całożyciowa, którą wykazują się na różnych poziomach niemal wszyscy ludzie, może stanowić w pedagogice pozytywną ideę przewodnią, oś, wokół której rozwijać się mogą inne idee i badania. Przemawiają za tym różne względy teoretyczne i praktyczne.

1. Twórczość i kreatywność to zjawiska złożone, które niełatwo badać. Ale jednocześnie to zjawiska, które w moim przekonaniu są bardzo interesującym przedmiotem badań pedagogicznych, może jednym z najciekawszych $\mathrm{w}$ tej dziedzinie nauki. Badania twórczości mogą się odbywać na czterech różnych poziomach:

- metateoretycznym (jak tworzy się teorie twórczości i jaka jest zawartość treściowa tych teorii?),

- teoretycznym (co mówią teorie twórczości na temat wszystkich lub wybranych aspektów tego zjawiska; wytworów, procesu, osoby tworzącej i uwarunkowań?),

- teoretyczno-praktycznym (jak formułować koncepcje wychowania do twórczości i pomocy w tworzeniu?),

- praktycznym (jak realizować programy pomocy w tworzeniu i jakie są ich efekty wychowawcze?).

Na wszystkich tych poziomach lub lepiej powiedzieć - we wszystkich tych typach badań pedagogicznych (zob. Palka, 2006) jest wiele do zrobienia i przed dociekliwym badaczem pedagogiem rysuje się szerokie pole problemowe. Pedagogika twórczości, choć rozwija się dynamicznie i notuje stały przyrost badań wszystkich czterech typów, to jednak wymaga stałej elaboracji (Szmidt, 2008). Zachęcając zatem przyszłych „pedagogów pozytywnych” do naukowej penetracji zjawiska twórczości i kreatywności, mogę wskazać kilka interesujących problemów wartych dalszej eksploracji1:

- Jakie teorie twórczości są dla pedagogiki i pedagogów najbardziej płodne, to znaczy mogą stanowić źródło nie tylko rzetelnych opisów przejawów ludzkiej kreatywności, ale również inspirację do nowych pytań badawczych? Czy te zadania spełniają lepiej teorie personologiczne, koncentrujące się na właściwościach podmiotu tworzącego, czy raczej teorie systemowe i społeczno-kulturowe,

${ }^{1}$ Wydaje się, iż polscy psychologowie twórczości po krótkim okresie wzmożonego zainteresowania problematyką twórczości i kreatywności pod koniec wieku XX i na początku nowego stulecia, w ostatnich latach niejako stracili naukowy napęd i nie powstają obecnie znaczące prace naukowe w dziedzinie „kreatologii” - nauki o twórczości. 
upatrujące przyczyn sukcesu twórczego w interakcji zdolności z czynnikami środowiska wychowawczego? Jaka jest zawartość teoretyczna głównych twierdzeń poszczególnych teorii i ich moc eksplanacyjna? Co jedne teorie thumaczą lepiej niż inne i dlaczego mogą być bardziej „użyteczne” w pedagogice pozytywnej?

- Jak tworzyć dobre programy pomocy w tworzeniu? Jak formułować cele strategiczne i operacyjne tych programów i na jakich przesłankach teoretycznych je opierać? Co uzasadnia konieczność formułowania tych celów: jakie względy cywilizacyjne, gospodarcze, kulturowe, społeczne czy osobiste? Dlaczego bycie kreatywnym stanowi imperatyw życiowy w nowym tysiącleciu?

- Jak pomagać dzieciom, młodzieży i dorosłym w tworzeniu, żeby aktywność twórcza była czynnikiem potęgującym dobrostan jednostkowy, ale i społeczny? Jakie zasady, metody, techniki i środki dydaktyki twórczości są w tych działaniach najlepsze, to znaczy najskuteczniejsze i poddają się innowacyjnemu rozwinięciu? Jakie efekty w skali mikro, mezo i makro mogą świadczyć o skuteczności programów wychowania do twórczości?

- Jak badać, identyfikować i oceniać przejawy kreatywności wszystkich generacji wieku? Jaką wartość mają poszczególne podejścia badawcze i metody badań twórczości: psychometryczne, biograficzne, studia przypadków, monografie, eksperymenty, badanie w działaniu? Które dostarczają trafniejszych i pełniejszych opisów i wyjaśnień różnorodnych form twórczej aktywności i jej uwarunkowań? Jakie są ich ograniczenia badawcze, analityczne i interpretacyjne? Czy badania pedagogiczne nad twórczością są swoiste i różnią się od podobnych badań psychologicznych lub socjologicznych?

To tylko niektóre zagadnienia, które wymagają większego wysiłku naukowego ze strony pedagogów. Twórczość jest tak złożonym zjawiskiem, przejawiającym się w tak różnych dziedzinach (sztuka, technika, rekreacja, nauka, sport, działalność publiczna i polityczna), że każde naukowe nią zainteresowanie rodzi nowe, często odkrywcze pytania.

2. Działania twórcze i ich efekty cieszą, poprawiają dobrostan i mają związek z poczuciem humoru i zadowoleniem z życia, a nie są tylko uzupełnianiem deficytu lub sublimacją napięć i nerwic. Od lat wyrażam takie przekonanie, bazując zarówno na obserwacjach potocznych, jak i na dobrze ugruntowanych wynikach badań naukowych (zob. O’Quin \& Derks, 1997; Tokarz, 2005; Czerw, 2010). Już z tego względu warto, aby pedagogika pozytywna zajęła się zagadnieniem związku kreatywności ze zdrowiem i ogólnym poczuciem dobrostanu i przeciwstawiała się deficytowemu modelowi kreatywności (Nakamura i Csikszentmihalyi, 2004). Przez całe stulecia, a i dzisiaj dosyć często, w rozważaniach o twórczości łączono jej najwybitniejsze przejawy z zaburzeniami zachowań i chorobami psychicznymi (zob. tekst A. Chmielińskiej w tym tomie). Przykłady chorych lub nieszczęśliwych poetów, pisarzy, kompozytorów i malarzy przysłoniły portrety poetów, pisarzy, kompozytorów i malarzy szczęśliwych. Miały służyć ugruntowaniu się tezy, iż twórczość, zwłaszcza mistrzowska i przełomowa, stanowi przyczynę lub 
skutek zaburzeń psychicznych. Do upowszechnienia się tej wizji trwałego związku twórczości wyższego lotu z patologią przyczyniły się jednostronne biografie twórców zaburzonych, filmy biograficzne poświęcone genialnym wariatom i sensacyjne artykuły prasowe, prezentujące spektakularne przykłady zachowań twórców zaburzonych i ich skutki. W kulturze masowej, ale i w refleksji naukowej o twórczości artystycznej na trwale zagościł obraz szalonego, wybitnego twórcy. Mass media bardzo rzadko pokazują losy wybitnego twórcy szczęśliwego, zaspokojonego, zadowolonego z życia i własnych osiągnięć - twórcy spełnionego. A przy tym miłego, uspołecznionego, sympatycznego i lubianego przez rodzinę oraz przedstawicieli danej dziedziny. Szczęście twórcy jest jednak gorszym tematem na pierwszą stronę tabloidu lub filmu biograficznego - nie przykuwa bowiem rozproszonej uwagi dzisiejszego masowego odbiorcy.

James Kaufman (2011, s. 105) pisze, iż „nikt nigdy nie napisał biografii jakiejś twórczej osoby dlatego, że była to osoba najzupełniej normalna”. I dalej: „Ludzie twórczy, którzy są dziwakami i odmieńcami lub cierpią na jaką́ chorobę psychiczną, stanowią o wiele lepszy materiał na fascynującą opowieść niż ludzie twórczy, którzy są nudni, ciężko pracują i mają udane życie małżeńskie" (tamże). Dlatego między innymi będzie rosła liczba biografii poświęconych twórczym dziwakom niż dobrze przystosowanym twórczym geniuszom, którzy wiodą szczęśliwe życie. Tymczasem bardziej dociekliwe i prowadzone bez tendencyjnych założeń badania nad twórczością wybitną pokazują, iż związek jej z zaburzeniami psychicznymi jest bardziej skomplikowany i nie taki jednostronny, jak przedstawiają to zwolennicy psychopatologicznej koncepcji twórczości (zob. Śmigórski, 2010; Kaufman, 2011). Istnieje wobec tego potrzeba wyrównania proporcji i konstruowania zharmonizowanego, wyrównanego obrazu twórcy i procesu twórczego, w którym zostaną pogodzone dwie orientacje: orientacja na brak i chorobę $z$ orientacją na dobrostan i zaspokojenie.

W tworzeniu tego obrazu twórcy spełnionego i szczęśliwego może pomóc pedagogiczne zorientowanie tematyki badań, które polega na wnikliwym badaniu sukcesu twórczego i samorealizacji poprzez twórczość. Możemy w przyszłych badaniach skupić się na następujących problemach:

- Co przyczynia się do tego, że aktywność twórcza jest wieńczona osiągnięciami celów na najwyższym poziomie? Jakie zasoby osobiste, rodzinne, społeczne pomagają $\mathrm{w}$ tym dziele, a jakie czynniki przeszkadzają? Jak twórcy spełnieni definiują swój sukces i gdzie upatrują jego źródeł?

- Jaka jest rola edukacji i akulturacji przyszłego twórcy w osiąganiu przez niego dobrostanu poprzez twórczość? Czy szkoła i kręgi wychowawcze umożliwiają w istocie dorastającym osobom możliwość tworzenia, jak chce Keith Sawyer (2012), czy raczej hamują jej naturalne przejawy, jak twierdzi większość badaczy? Szkoła szansą czy zagrożeniem dla naturalnej kreatywności dzieci?

Możemy również w ramach przyszłych badań w nurcie pozytywnym wykorzystać podejście biograficzne lub studia indywidualnych przypadków i objąć 
badaniami twórców szczęśliwych, żyjących, jak i z dawnych epok. Mimo wielu oczekiwań kierowanych pod adresem psychologów twórczości, których badania korelacyjne miały ostatecznie wyjaśnić istotę procesu twórczego i stworzyć uniwersalną charakterystykę osobowości twórczej, nadal nie dysponujemy taką wiedzą. Jaki bowiem może być pożytek pedagogiczny z „odkryć” psychologów eksperymentalnych, mówiących o tym, iż osoby twórcze są otwarte na świat, buntownicze, nonkonformistyczne i wytrwałe w dążeniu do trudnych celów? Wszak wie o tym każdy rozgarnięty i oczytany ślusarz narzędziowy! Badania nad osobowością twórców, zwłaszcza psychometryczne i laboratoryjne, idą w setki i tysiące (zob. Feist, 2010), a mimo to przynoszą informacje diagnostyczne o cechach artefaktów. Dowiadujemy się z nich o tym, co i tak wiemy bez badań - że twórcy są otwarci na informacje płynące $\mathrm{z}$ różnych źródel, tolerują sprzeczności bez wpadania w nerwicę, myślą oryginalnie i nieszablonowo, są pracowici, zaangażowani, bardzo produktywni i często potrafią długo czekać na gratyfikację. Tymczasem badania twórców autentycznych, prowadzone poza laboratoriami naukowymi, często zaprzeczają tej wiedzy: wielu wybitnych twórców wcale nie jest otwartych na świat, z trudem toleruje wieloznaczność, często wpada w schematy myślowe i nie potrafi tworzyć bez szybkiej nagrody.

Pedagogice pozytywnej w tym nurcie badań może pomóc skierowanie reflektorów badawczych na twórców rzeczywistych, mających znaczące dokonania w różnych dziedzinach i poprzez śledzenie ich biografii konstruowanie pedagogicznych modeli twórczości szczęśliwej i udanej (zob. artykuł Moniki Modrzejewskiej-Świgulskiej w tym tomie).

\section{Po drugie, zdolności}

Drugim obszarem zainteresowań pedagogiki pozytywnej, oprócz twórczości i kreatywności, mogą być w moim przekonaniu zdolności i uzdolnienia wszystkich generacji wieku. Problematyka zdolności ma ogromną literaturę przedmiotu, ale głównie w USA, Anglii i krajach Europy Zachodniej, lecz nie w Polsce. Na wszystkich poziomach badań - metateoretycznym, teoretycznym, praktycznym - zdolności doczekały się w literaturze anglosaskiej ostatnich 20 lat tak wielu publikacji, że nie sposób objąć lekturą nawet tych najważniejszych. Mamy tu bowiem zarówno prace sumujące całość problematyki pedagogiki zdolności (np. Colangelo i Davis, 2003; Davis i Rimm, 2004; Davis, 2006; Smutny, ed., 1998; Pfeiffer, ed., 2008), jak i dobrze ugruntowane $\mathrm{w}$ teorii i badaniach prace poświęcone koncepcjom zdolności (np. Sternberg i Davidson, eds, 2005; Sternberg i in., 2011), edukacji uczniów zdolnych (12-tomowa seria Essential Readings in Gifted Education pod redakcją Sally Reis wydawnictwa Corwin Press; licząca prawie 800 stron praca Critical Issues and Practices in Gifted Education pod redakcją Pluckera i Callahan, 2008; oraz całą serię poświęconą uczniom zdolnym wydawnictwa Prufrock Press; Robinson i in., 2007), jak również krytyczne przeglądy badań nad uczniem zdolnym i efektywnością programów wspierania zdolności (Van Tassel-Baska, ed., 2008; Thompson i Subotnik, eds, 2010). Nie wymieniam tu tysięcy doniesień z badań 
oraz setek poradników dla rodziców i nauczycieli dzieci zdolnych oraz materiałów metodycznych dla osób prowadzących zajęcia wspierające zdolności. Można powiedzieć, iż wiedza o zdolnościach i uzdolnieniach nigdy nie była tak obfita.

Pewne ożywienie zainteresowania tą tematyką widać również w naszym kraju. W ostatnich latach wychodzi wreszcie pierwszy z prawdziwego zdarzenia podręcznik akademicki o zdolnościach i uczniach zdolnych, autorstwa Wiesławy Limont (2010), który poprzedziła i któremu towarzyszy seria rozpraw zbiorowych pod redakcją tej autorki oraz jej współpracowników (np. Limont i Cieślikowska, red., 2005; Limont i in., red., 2010). Opublikowane zostały badania pedagogiczne Teresy Gizy (2006) oraz Beaty Dyrdy (2012), dotyczące problemów kształcenia uczniów zdolnych w szkołach wielu województw, diagnozujące niewesoły stan praktyki edukacyjnej. Nauczyciele i pedagodzy doczekali się wreszcie dobrze ugruntowanych w wiedzy naukowej poradników na temat zdolności i edukacji uczniów zdolnych (Eby i Smutny, 1998; Landau, 2003; Moenks i Ypenburg, 2007; Czaja-Chudyba, 2009). Pedagogika zdolności dzięki próbom konceptualizacji przedmiotu i celów badań (Giza, 2009; Dyrda, 2012) powoli emancypuje się i zaczyna stawać poważną subdyscypliną pedagogiki. A mimo to musi nadrabiać wieloletnie zaległości w stosunku do świata.

Do podstawowych problemów pedagogicznych, związanych z refleksją naukową nad zdolnościami, należą następujące dylematy (zob. Davis, 2006; Gallagher, 2008; Giza, 2006; Heller i Schofield, 2008; Sternberg i in., 2011; Limont, 2010; Dyrda, 2012):

- Jak rozumiemy zdolności i uzdolnienia oraz talent? Czy zdolności są sprawnością, biegłością w wykonywaniu jakichś określonych czynności, czy raczej kompetencją ogólną, niespecyficzną?

- Kim jest uczeń zdolny i zdolny dorosły? Jakimi właściwościami psychicznymi, osobowościowymi i społecznymi się cechują? I czym różnią się uczniowie zdolni w różnych dziedzinach wiedzy i aktywności?

- W jaki sposób identyfikujemy (diagnozujemy) zdolne dzieci, młodzież i dorosłych? Przy pomocy jakich metod i technik dokonywać rozpoznania zdolności ogólnych i specjalnych? Jakie są pomyślne warunki rozwoju zdolności wybitnych i talentu?

- Czy rodzina i szkoła wspiera należycie dzieci zdolne? Jak dobierać uczniów zdolnych do programów edukacyjnych, jak dokonywać selekcji i naboru do programów stypendialnych i rozwojowych?

- Jak konstruować te programy i - szerzej - politykę oświatową nakierowaną na diagnozę i wsparcie zdolności dzieci i młodzieży?

W sumie dylematy pedagogiczne dotyczące zdolności sprowadzają się do trzech głównych problemów: 1) rozumienia, identyfikacji i rozpoznawania zdolności; 2) tworzenia i realizacji programów opieki i kształcenia uczniów zdolnych oraz 3) ewaluacji kształcenia uczniów zdolnych. Udzielono już wielu odpowiedzi na te pytania, wszystkie one są ważne dla pedagogiki zasobów twórczych 
(pozytywnej). Moim zamiarem w tym miejscu nie jest referowanie tych odpowiedzi, bo wymagałoby to poświecenia im wielu stron rozważań, ponadto prace Teresy Gizy (2006), Wiesławy Limont (2010), Iwony Czai-Chudyby (2009) i Beaty Dyrdy (2012) zawierają bardzo bogaty arsenał informacji na ten temat i warto do nich sięgnąć. W tym miejscu chciałbym krótko zreferować własne stanowisko teoretyczne, dotyczące niektórych z powyższych zagadnień.

1. Badania pedagogiczne przeprowadzone $\mathrm{w}$ ostatnich latach w szkołach polskich, między innymi przez cytowane wyżej autorki, wyraźnie wskazują niepokojące symptomy edukacji dzieci zdolnych:

- nauczyciele szkół polskich nie interesują się zdolnościami i uzdolnieniami uczniów, może poza zdolnościami poznawczymi (akademickimi);

- mają nikłą wiedzę o naturze zdolności, ich rodzajach i rozwoju;

- nie prowadzą w sposób świadomy i systematyczny identyfikacji zdolności uczniów;

- nie znają wielu podstawowych narzędzi diagnozowania zdolności i twórczości uczniów.

Konsekwencją jest otaczanie zdolności i uczniów zdolnych wieloma potocznymi przekonaniami, niemającymi uzasadnienia w wiedzy naukowej. Można je nazwać mitami o uczniu zdolnym. Mit w tym przypadku oznacza potoczne przekonanie, stereotyp, którego treść dotyczy właściwości ucznia zdolnego i jego funkcjonowania w szkole. Wśród powszechnie wyrażanych i podzielanych nauczycielskich mitów o uczniu zdolnym królują następujące mity:

1) uczniowie zdolni to ci, którzy mają najlepsze oceny szkolne;

2) uczniowie zdolni poradzą sobie w szkole i w życiu bez specjalnego wsparcia ze strony szkoły - z tego prostego powodu, że są właśnie zdolni;

3) uczniowie zdolni są kłopotliwi;

4) zdolności uczniów najlepiej pobudzać przy pomocy olimpiad przedmiotowych i konkursów;

5) większość uczniów zdolnych to tzw. ,zdolne lenie”.

Inne mity:

- z klasą pełną uczniów zdolnych łatwiej się pracuje;

- nie potrzeba prowadzić specjalnych diagnoz - uczniowie zdolni sami się ujawnią w toku lekcji;

- wielu uczniów zdolnych to odludki, mało uspołecznieni prymusi, których nikt nie lubi.

Robert J. Sternberg (Sternberg i in., 2011, s. 11-12) twierdzi, iż najpowszechniejsze są następujące fałszywe przekonania o uczniach zdolnych:

- uczniowie zdolni to uczniowie mający wysokie IQ, zajmujący od 3 do $5 \%$ populacji;

- uczniowie zdolni i utalentowani to taka sama grupa, niezmienna od setek lat, a ich zdolności oparte są na tych samych podstawach. 
Polskie psycholożki, Ewa Czerniawska i Maria Ledzińska (2011, s. 286), piszą zaś: „Przekonania na temat uczniów zdolnych to nierzadko krzywdzące stereotypy". Zgodnie z nimi uczniowie zdolni:

- to jednostki słabo przystosowane, oryginalne, a nawet ekscentryczne;

- zachowują się dziwacznie;

- są trudni w kontakcie;

- stale są wycofani i bezradni w podejmowaniu i rozwiązywaniu problemów życia codziennego.

Wyniki badań diagnostycznych (Giza, 2006; Dyrda, 2012) opisują następujące niepokojące zjawiska:

- Nauczycieli bardziej zajmują diagnozy negatywne niż pozytywne. Jeśli prowadzą jakąkolwiek diagnozę, to prawie wyłącznie wtedy, gdy uczeń sprawia trudności wychowawcze (Giza, 2006).

- Z badań wynika, iż spośród wielu uzdolnień u swoich uczniów nauczyciele potrafią wskazać sześć rodzajów: sportowe, techniczne, plastyczne, muzyczne, matematyczne i literacko-językowe (tamże, s. 84).

- W 445 szkołach polskich, przebadanych przez Teresę Gizę, co trzeci nauczyciel nie ma opinii (pojęcia?) w sprawie kryteriów rozpoznawania uczniów zdolnych.

- Najczęściej i najłatwiej nauczyciele identyfikują u uczniów uzdolnienia artystyczne.

- Dokonując selekcji uczniów zdolnych, nauczyciele kierują się dwoma kryteriami: średnią ocen oraz rodzajem zaobserwowanych zdolności.

- Dziewczęta dwukrotnie częściej są wskazywane jako zdolne. Zdolności częściej są rozpoznawane u uczniów starszych. Trafność nominacji nauczycielskich - ok. $20 \%$.

- Zdolności twórcze i twórczość są sprowadzane wyłącznie do działań artystycznych.

- W ponad 44\% placówek nie są znane żadne pozaszkolne możliwości wspierania uzdolnionych uczniów.

- Blisko 80\% spośród prawie 400 przebadanych przez Beatę Dyrdę (2012) nauczycieli przyznaje, iż w ich szkole nie prowadzi się celowego i systemowego procesu identyfikacji zdolności uczniów.

- Nauczyciele w swych diagnozach zdolności bazują głównie na obserwacji, intuicji, wyczuciu oraz ocenach szkolnych.

- Nauczyciele uważają, iż w szkole najlepiej wspiera się rozwój zdolności artystycznych oraz sportowych, najsłabiej - zdolności społecznych i uzdolnień naukowych.

- Formy zajęć specjalnych dla uczniów zdolnych są zdominowane przez tradycyjne zajęcia pozalekcyjne, kółka zainteresowań, konkursy przedmiotowe i olimpiady. 
Jeden z twórców szkoły specjalnej dla uczniów zdolnych w Austrii, Andreas Salcher (2009, s. 50), podaje bardzo znamienny fakt, dobrze ilustrujący podejście wielu nauczycieli do dziecka zdolnego. Oto mama pewnego szczególnie uzdolnionego ucznia klasy I, która chciała dowiedzieć się, jak sobie radzić z tym, że uczy on się wszystkiego szybciej i lepiej niż jego koledzy, została przez nauczycielkę całkiem poważnie poinformowana: „Proszę się nie martwić, najpóźniej do trzeciej klasy wszystko się wyrówna”. Warto zapytać: co się „wyrówna”? I w jaki sposób się wyrówna: czy inne dzieci „wyrównają” do poziomu ucznia zdolnego, czy uczeń zdolny „wyrówna” do poziomu uczniów przeciętnych?

2. Zacząc trzeba od zrozumienia zdolności i talentu. Wokół tych pojęć, za sprawą programów telewizyjnych, mających promować osoby „utalentowane” (zob. artykuł Joanny Okołowicz w tym tomie), narosło wiele fundamentalnych nieporozumień. W moim przekonaniu o talencie możemy mówić w odniesieniu do wybitnych zdolności, spotykanych u niewielu ludzi, o zdolnościach i uzdolnieniach - w odniesieniu do niemal wszystkich ludzi. Warto więc posługiwać się pojęciami „zdolności”, „uzdolnienia” i „talent” z większą ostrożnością, żeby nie straciły one sensu.

Zdolności są na ogół rozumiane jako (Eby i Smutny, 1998; Limont, 2010; Sternberg i in., 2011; Davis, 2006; Dyrda, 2012):

1) potencjalna szansa, aktualnie niewystępująca, ale którą można nabyć;

2) biegłość, sprawność w wykonaniu jakiejś czynności;

3) aktualna możliwość jednostki do wykonania jakiejś czynności;

4) indywidualna właściwość człowieka, zapewniająca mu powodzenie w jakimś działaniu.

Uzdolnienia to: zdolności kierunkowe, specjalne, odpowiednio ukierunkowane, które warunkują ponadprzeciętny poziom wykonania jakiegoś rodzaju działalności, na przykład naukowej, artystycznej, fizycznej, technicznej itp. Inaczej - zdolności specjalne: poznawcze, językowe, literackie, matematyczne, techniczne, muzyczne, plastyczne, pedagogiczne, społeczne $\mathrm{i}$ in.

Talent to specyficzny kompleks cech indywidualnych, ujawniających się już w okresie wczesnego dzieciństwa u niewielu osób, prowadzący do szczególnego mistrzostwa w jakiejś dziedzinie (Simonton, 2010). Inaczej - bardzo wysoki poziom określonej zdolności specjalnej lub wiązki uzdolnień, które przejawiają się w ponadprzeciętnej łatwości nabywania wiedzy lub sprawności w jakiejś dziedzinie (talent muzyczny, plastyczny, aktorski, literacki, sportowy itp.). Pojęcie geniusza odnosi się do najwyższego poziomu funkcjonowania intelektualnego i twórczego. Geniusz zatem to osoba (tamże):

1) wybitnie uzdolniona;

2) uznana społecznie;

3) cechująca się mistrzostwem w jakiejś dziedzinie.

Dean K. Simonton (2010), którego pogląd tu referuję, upowszechnia od dawna znaną tezę o wybitnych, genialnych zdolnościach. Teza ta jest wynikiem wielu żmudnych badań historiometrycznych Simontona (zob. ich przegląd: 1997; 2004; 
2010), a twierdzenia podobne do niej znajdziemy w wielu dobrych biografiach wybitnych twórców. Mówi ona, iż na geniusza składają się trzy ważne cechysyndromy: wysoka produktywność, wysoka oryginalność i wybitna twórczość poświadczona rzeczywistymi osiągnięciami i ciężką, wytężoną pracą.

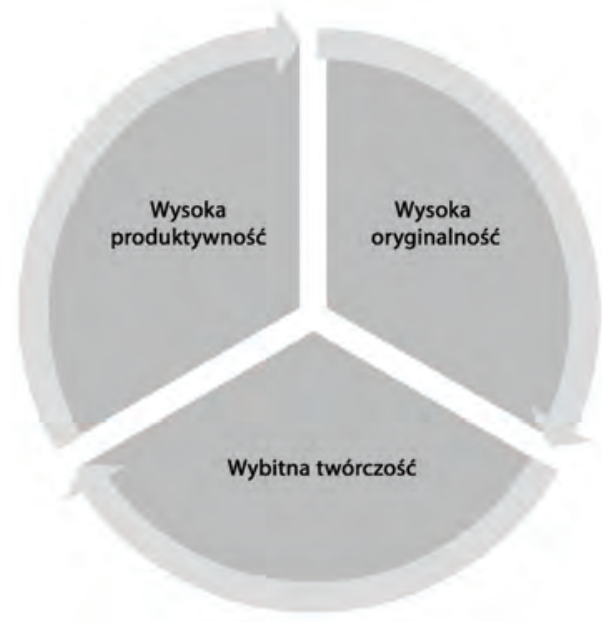

Rys. 1. Struktura geniuszu według D. K. Simontona

(Rzeczywiste, mierzalne osiągnięcia + ciężka, wytężona praca (ok. 10 lat))

Źródło: oprac. własne na podstawie Simonton, 2010

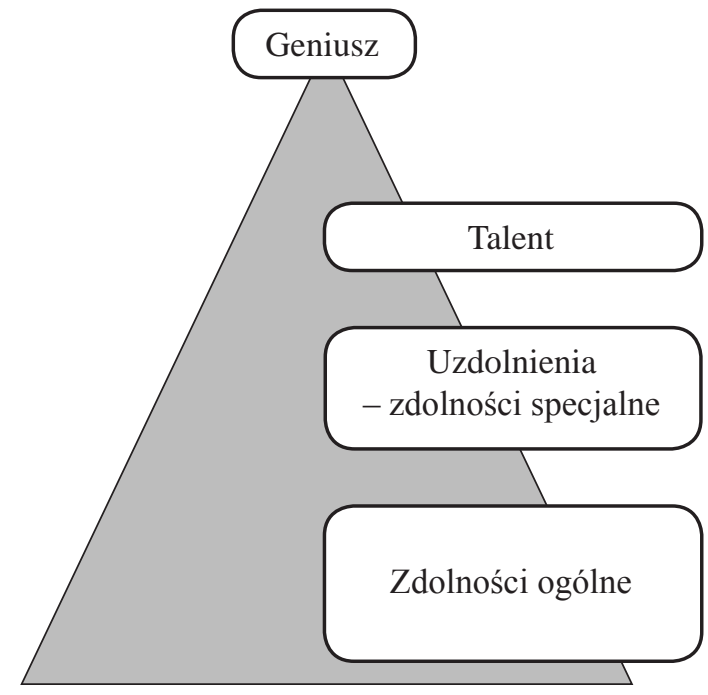

Rys. 2. Hierarchia zdolności

Źródło: oprac. własne

Na ogół wyróżnia się (Limont, 2010) trzy podstawowe grupy uczniów zdolnych w klasie: 
1) uzdolnieni intelektualnie - odnoszą sukcesy w uczeniu się;

2) uzdolnieni w różnych dziedzinach - uczniowie zdolni w sztuce, technice, sporcie itp;

3) uzdolnieni twórczo - charakteryzują się zdolnościami kreatywnymi w jednej lub kilku dziedzinach, wymyślając nowe i oryginalne rozwiązania.

Nas, z racji głównego zasobu, którym interesuje się pedagogika pozytywna, najbardziej „obchodzi” uczeń zdolny twórczo. Rozszerzoną charakterystykę ucznia twórczego przedstawiłem w innym miejscu (Szmidt, 2012) - tutaj warto wymienić jego główne właściwości w kontekście zdolności i uzdolnień. Na początek jednak ważna uwaga: uczeń zdolny nie musi być twórczy, natomiast każdy uczeń twórczy jest zdolny w ramach dziedziny, w której jest twórczy. Uczeń zdolny może być, i tak często się dzieje, biegły w zapamiętywaniu i przypominaniu sobie wiadomości i w ich zastosowaniu do rozwiązywania problemów zamkniętych. To ten uczeń, który bardzo często odpowiada jako pierwszy na wszelkie pytania nauczyciela, ale głównie na takie, które wymagają przypomnienia sobie wiedzy, czasem nawet wyrafinowanej i trudnej. Ale jednocześnie uczeń ten niczego nowego nie wymyśla, nie tworzy, a jego pomysły nie są oryginalne. Wobec tego można powiedzieć, że wiele zdolności, które przejawiają nasi uczniowie, nie wiąże się z aktywnością twórczą, nie generują oni bowiem nowych i wartościowych rozwiązań, choć szybciej i sprawniej opanowują wiele umiejętności i wiadomości.

Istotą jest to, iż zdolności twórcze ucznia manifestują się w umiejętności znajdowania nowych problemów i generowania nowych i oryginalnych rozwiązań. Uczeń twórczy jest zatem pomysłowy i wymyśla nowości, które mają określoną, przynajmniej subiektywną wartość. Uczniowie uzdolnieni twórczo zadają dociekliwe pytania, potrafią wcześniej niż inni odkryć paradoks, brak w wiedzy, nieścisłość lub sprzeczność oraz podać w wątpliwość jakieś ugruntowane przekonanie - cechuje ich wysoki poziom myślenia pytajnego (Szmidt, 2006). Poszukują rozwiązań nietypowych i mało popularnych, nie podążają za innymi, nie naśladują znanych sposobów rozwiązywania problemów - dążą do zaznaczenia własnej oryginalności. Często buntują się przeciwko schematom i normom narzuconym w klasie przez nauczyciela lub lidera opinii. Mają zatem opinię nonkonformistów, oryginałów, uczniów niesfornych, kłopotliwych, mających własne zdanie lub podążających własnymi ścieżkami. Inne cechy uczniów twórczych to: płynność i giętkość myślenia, otwartość na doświadczenia, bawienie się pojęciami i problemami (Co by było, gdyby...?), swoiste poczucie humoru, które może być niezrozumiałe dla nauczyciela $\mathrm{i}$ innych uczniów, tolerancja dla ryzyka i podejmowanie trudnych wyzwań poznawczych. Uczniowie twórczy nie muszą przejawiać wysokich zdolności poznawczych lub specjalnych w jakiejś określonej dziedzinie, z tego względu rzadko należą do grupy prymusów.

Przypisuje się im wiele cech negatywnych, charakterystycznych również dla wszystkich uczniów zdolnych, nie tylko twórczych: chęć ciągłego imponowania, rywalizowanie z innymi o wszystko, dominacja, zarozumiałość, pycha, 
lekceważenie okazywane rówieśnikom i nauczycielom, egocentryzm, egoizm, koncentracja na sobie, trudność z przechodzeniem od wiadomości do umiejętności, przesadny perfekcjonizm, chwiejność emocjonalna, nieśmiałość lub nadpobudliwość, agresywność bądź pasywność.

Dla pedagogiki pozytywnej, w której zdolności mogą być postrzegane jako jeden z głównych zasobów ludzkich (zobacz artykuł J. Okołowicz w tym tomie), wynikają poważne postulaty do przyszłych badań. Badając uczniów zdolnych, powinniśmy pamiętać, iż nie zawsze są to ci uczniowie, którzy mają najlepsze oceny szkolne i najwyższy iloraz inteligencji. Rozpoznanie zdolności, pomoc i wsparcie uczniom zdolnym są konieczne, bo bez nich nie rozwiną swoich potencjałów i nie staną się zdolnymi dorosłymi - dlatego warto zwalczać mit o tym, iż „zdolni poradzą sobie sami”. Zdolni uczniowie mają wiele problemów emocjonalnych i motywacyjnych (dysharmonia rozwoju) i przez to są kłopotliwi dla nieprzygotowanych nauczycieli, zwłaszcza uczniowie zdolni twórczo. Olimpiady i konkursy przedmiotowe czy artystyczne, tak często stosowane w szkołach polskich jako główny sposób stymulowania zdolności (Dyrda, 2012), motywują tylko niektórych uczniów zdolnych - duża ich część nie lubi jednak rywalizacji i słabo w niej wypada. Wyrażam przekonanie (Szmidt, 2011), iż dominacja konkursów i innych form rywalizacyjnych w celu motywowania uczniów zdolnych do rozwoju jest nieświadomym przyznaniem się nauczycieli do porażki dydaktycznej, polegającej na tym, iż inne - nierywalizacyjne formy kształcenia - po prostu nie działają stymulująco na uczniów zdolnych w środowisku polskiej szkoły.

Tymczasem praca z uczniem zdolnym może być prawdziwym wyzwaniem dla znudzonego nauczyciela i stać się nową, bardzo satysfakcjonującą misją pedagogiczną, ale należy jej się tak samo uczyć, jak pracy z uczniem o specjalnych potrzebach edukacyjnych.

\section{Po trzecie, mądrość}

Rzadko która kategoria teoretyczna wywołuje tyle kontrowersji wśród badaczy (filozofów, psychologów, pedagogów, socjologów) i równocześnie jest tak bardzo nieobecna we współczesnej naukowej refleksji nad wychowaniem i kształceniem. Mądrość wydaje się być tematem codziennych rozmów i dyskusji, stałym kryterium, według którego ocenia się postępowanie ludzi i twierdzenia naukowe, a zarazem trudno znaleźć $\mathrm{w}$ jakimkolwiek podręczniku pedagogiki tematy związane z mądrością (Szmidt, 1994). Obecna w rozważaniach filozofów od tysiącleci, od czasów Sokratesa i Platona, dzisiaj wydaje się mniej koncentrować uwagę nie tylko pedagogów. Zwłaszcza w Polsce publikacje na temat mądrości, jej składników i rozwoju, można policzyć na palcach jednej ręki. Wydaje się być, żeby użyć kategorii Zbigniewa Kwiecińskiego, nieobecnym dyskursem w pedagogice. Tym bardziej warto się o nią upomnieć w przyszłej pedagogice pozytywnej.

Kłopoty z mądrością jako przedmiotem rozważań w pedagogice nie dziwią - uważa się, że mądrość jest jednym z najmniej precyzyjnych i najbardziej 
wieloznacznych pojęć funkcjonujących w naukach społecznych (Pomykało, 1998). Wystarczy nadmienić, że V. P. Clayton (1975) zebrała aż 165 opisowych określeń, które są stosowane do charakterystyki mądrej osoby. Trudności definicyjne i kryterialne sprawiły, iż problematyka mądrości tylko epizodycznie była przedmiotem badań naukowych. Kryteria mądrości są bowiem względne: raz za mądrość uważamy wiedzę życiową i doświadczenie praktyczne pomagające skutecznie działać w sytuacjach codziennych, innym razem mądrość kojarzona jest z wiedzą akademicką dotyczącą filozoficznych problemów bytu, poznania i losu człowieka, a jeszcze innym razem - z ogólnoludzką kulturą poznania i postępowania (style poznawcze i postawa metapoznawcza). Jak pisze Robert J. Sternberg (1990), redaktor ważnego tomu rozważań naukowych na temat mądrości, pełne i prawidłowe rozumienie mądrości wymaga prawdopodobnie więcej mądrości niż każdy z nas posiada. Nie oznacza to jednak, że powinniśmy zaniechać dociekań naukowych na ten temat. Nawet w sytuacji, w której mądrość „,iągle jawi się nam jako cecha nadzwyczaj tajemnicza, o której większość sądzi, że ją posiada, a mniejszość ma ją za ideał niedościgły" (Pietrasiński, 2001, s. 9-10).

A zatem mądrość wydaje się wymiarem niezwykle trudnym do naukowego zoperacjonalizowania. Definicje i koncepcje mądrości nawiązują nie tylko do zdolności poznawczych, wiedzy i inteligencji człowieka, ale do twórczości, doświadczenia jednostki, umiejętności podejmowania decyzji w sytuacjach trudnych i ryzykownych, dokonywania prawidłowej oceny sytuacji społecznych. Mądrość wiąże się nierozerwalnie z wartościami uznawanymi i/lub realizowanymi przez człowieka, preferencje w zakresie wartości różnicują też określone rozumienie mądrości. W najszerszym rozumieniu mądrość postrzegana jest jako integracyjny aspekt ludzkiego życia: łączy doświadczenie, zdolności poznawcze i emocje, umożliwiając podejmowanie trafnych decyzji na poziomie indywidualnym i społecznym (Sękowski, 2001). Na przeciwległym biegunie mądrość jest utożsamiana z pragmatyczną wiedzą poznawczą, dzięki której jednostka działa efektywnie i osiąga status eksperta (Baltes, Smith, 1990). Pomiędzy tymi biegunami mieszczą się inne stanowiska teoretyczne, które szerzej opisałem w innym miejscu (Szmidt, 2002).

Rzecz jasna, tematyka mądrości, jej składników, procesów i rozwoju nie jest nowa (jak stwierdzają Birren i Fisher, pierwsza pisemna koncepcja mądrości została odkryta w Egipcie przed 3000 r. p.n.e). Historię naukowej refleksji nad mądrością Daniel N. Robinson (1990) zaczyna od Sokratesa i wyróżnia trzy historyczne definicje mądrości: 1) stanowisko greckie łączy mądrość z intelektualnym, moralnym i praktycznym życiem, które toczy się w zgodzie z prawdą i pięknem, 2) w koncepcji chrześcijańskiej mądrość wiąże się z postępowaniem prowadzącym do przeżyć metafizycznych, absolutnej prawdy zgodnej z pierwiastkiem boskim, 3) współcześnie mądrość rozpatrywana jest w kontekście naukowych badań dotyczących praw rządzących materią i ruchem. Podobne okresy w rozwoju pojęcia mądrości wyróżnia Wojciech Pomykało (1998, s. 226), który podkreśla szczególne znaczenie europejskiego Odrodzenia jako „okresu największego, najbardziej 
dynamicznego rozkwitu mądrości”. Jest to też, według niego, ostatni okres, w którym myśliciel, filozof czy twórca mógł jeszcze poznać całokształt dotychczasowej wiedzy naukowej i dokonać jej syntezy. Po tym okresie, gdy nastąpił gwałtowny rozwój i emancypacja dyscyplin naukowych, wiedza stała się niemożliwa do objęcia dla jakiegokolwiek mędrca. Problematyka mądrości obecna w rozważaniach naukowych od czasów Sokratesa została, zdaniem Pomykały, „wysłana na banicję" przez neopozytywistów, którzy uznali ją za kategorię mało precyzyjną, wieloznaczną, a więc - zgodnie z ich podejściem metodologicznym - niedefiniowalną w języku terminów operacyjnych. „Nie bez ich wpływu z psychologii też wykreślono to pojęcie, zastępując je pojęciem inteligencji, które miało się (w dużej mierze rzekomo) okazać o wiele bardziej precyzyjne i wartościowe badawczo. Za tymi dwoma dziedzinami wiedzy < wygoniono> też pojęcie mądrości z większości dzieł socjologicznych, pedagogicznych i innych. Odtąd mądrością zaczęli się zajmować wyłącznie poeci, powieściopisarze, publicyści. [...] Słowem, mądrość funkcjonowała od tego czasu bardziej poza obrębem wiedzy i nauki niż w jej obrębie" (Pomykało, 1998, s. 227). Zdaniem autora, kłopoty nauk pedagogicznych i innych z mądrością mają swe przyczyny w niechęci uczonych do tworzenia syntez, ponadto $\mathrm{w}$ dominacji matematyki i metod psychometrycznych w badaniach złożonych zjawisk, co doprowadziło do postrzegania mądrości jako pojęcia anachronicznego, mało przydatnego do opisu i wyjaśniania ludzkich zachowań. Podobnie działo się w psychologii, w której dominujący w XX w. behawioryzm „czuł odrazę” w stosunku do wszelkich „konotacji mentalnych”, zawartych w studiach naukowych nad mądrością (Birren, Fisher, 1990, s. 317).

Wydaje się jednak, że w ostatnich 20 latach mamy do czynienia z pewnym renesansem pojęcia mądrości w filozofii, psychologii, socjologii $\mathrm{i}$ „w minimalnym stopniu w pedagogice" (Pomykało, 1998, s. 227). Być może rację ma autor monografii na temat mądrości, Zbigniew Pietrasiński (2001), który twierdzi, iż mądrość nie jest dziś ideałem wychowania, ale jest w cenie. W związku z tym nie należy jego zdaniem rezygnować z mądrości jako celu kształcenia. Mądrość nie musi wyznaczać głównego celu procesu kształcenia, może być celem uzupełniającym. Niestety, istnieje wiele przeszkód, które przyczyniają się do rezygnacji pedagogów i pedagogiki z tego celu. Po pierwsze, o czym już wspominaliśmy, słowo „mądrość” ma zbyt wiele znaczeń i za każdą definicją kryje się inny ideał wychowania (nacisk na wiedzę, na myślenie lub na rozsądne działanie). Po drugie, ,mądrość wydaje się ideałem dostępnym tylko nielicznym za cenę żmudnych i niekończących się starań. Ma do niego przybliżać słuchanie rad w dzieciństwie i gromadzenie doświadczeń aż po starość. To nie jest pociągająca perspektywa w czasach fascynacji szybkim osiąganiem jasnych i dokładnie zaplanowanych celów. A ponadto nie wiadomo, jak można mierzyć postępy na drodze do mądrości, a bez takich pomiarów nowoczesne oddziaływania kształcące są trudne do pomyślenia" (Pietrasiński, 2001, s. 19). Po trzecie, kolejne utrudnienie tkwi w przekonaniu większości ludzi, że są już dostatecznie mądrzy i nie ma żadnego powodu, 
by stawiać taki cel rozwojowy. W naszych czasach, zdaniem Pietrasińskiego, mało kto czyta dzieła uczące mądrości, wydaje się też, że literatura na ten temat nie wytrzymuje konkurencji niezliczonych poradników na wszystkie niemal tematy życiowe, a być może nie nadąża po prostu za duchem czasu. Można mądrzeć - konkluduje autor - nawet nie stawiając sobie takiego celu. „Przyrost wiedzy i sprawności myślenia bywa niezamierzonym efektem ubocznym innych działań. Człowiek stale uwikłany w rozwiązywanie wielu spraw spornych, a nie mający dyktatorskiej władzy, uczy się patrzeć na sprawy z wielu perspektyw, choćby wcale nie miał tego na celu. Trudno jednak wątpić, że wyraźne postawienie sobie celu przybliża doń jeszcze skuteczniej” (Pietrasiński, 2001, s. 19).

Nie należy więc rezygnować z mądrości jako celu integrującego poczynania edukacyjne, cel taki i drogi prowadzące do niego Pietrasiński formułuje, tworząc również rozbudowaną poznawczą koncepcję mądrości.

1. Problematyka pedagogiczna mądrości sprowadza się nie tylko do rozumienia tego fenomenu, ale do pytania o to, czy procesy i składniki mądrości są możliwe do budzenia oraz rozwijania? Czy możliwy jest rozwój mądrości i - jeśli tak - to jakie zabiegi wychowawcze i dydaktyczne mogą temu służyć? Opracowano współcześnie wiele koncepcji teoretycznych mądrości i ich składników (zob. Szmidt, 2002), do najważniejszych dla pedagogiki pozytywnej należy zaliczyć następujące koncepcje:

- Mądrość jako pragmatyczna wiedza ekspercka - koncepcja Baltesa i Smitha (1990; Baltes i in., 2004), którzy postrzegają mądrość jako wiedzę ekspercką związaną z podstawową pragmatyką życia.

- Mądrość jako równowaga pomiędzy wiedzą a zwątpieniem - teoria Johna A. Meacham (1990), który twierdzi, że mądrość jest świadomością omylności i zawodności wiedzy oraz dążeniem do zachowania równowagi między wiedzą (knowing) a zwątpieniem (doubting). „Wiek i starzenie się nie stanowią istoty mądrości” - twierdzi Meacham (1990, s. 104).

- Mądrość jako zdolność dostrzegania problemów (problem finding) i zadawania właściwych pytań - koncepcja Neila Postmana (2001). Przez mądrość rozumie on zdolność rozróżniania, które dziedziny wiedzy są przydatne do rozwiązywania istotnych problemów. „Wiedza [...] to jedynie zorganizowane informacje. Jest samowystarczalna, zamknięta w jednym systemie informacji o świecie. Można mieć dużą wiedzę o świecie, lecz być całkowicie pozbawionym mądrości” (Postman, 2001, s. 105).

- Mądrość rozumiana w terminach stawiania i odkrywania pytań - koncepcja Patrici Kennedy Arlin (1990), która wydaje się łączyć stanowiska Postmana i Meachama.

- Mądrość jako holistyczny proces poznawczy - model Mihaly Csikszentmihalyi i Kevina Rathunde (1999), którzy rozpatrują mądrość ze stanowiska ewolucyjno-hermeneutycznego i postrzegają ją jako zjawisko złożone z trzech istotnych 
wymiarów: procesu poznawczego, wskazówek niezbędnych do działania i wartości osobistych prowadzących do dobrego samopoczucia.

- Mądrość jako wysoka kultura poznawcza - koncepcja Zbigniewa Pietrasińskiego. Zbigniew Pietrasiński (2001) jest autorem jednej z nielicznych w świecie psychopedagogicznej monografii poświęconej w całości zjawisku mądrości, w której deklaruje odstąpienie od traktowania mądrości jako tajemniczego dorobku pojedynczych umysłów na rzecz widzenia w niej ,,instrumentarium przejmowanego ze skarbnicy osiągnięć pokoleń" (Pietrasiński, 2001, s. 10). Mądrość postrzegana jest przez autora przez pryzmat nagromadzonych przez wieki reguł i metod określanych jako „programy myślenia”. Programy te tworzą konstrukt nazywany przez Pietrasińskiego kulturą poznawczą. „Mądrość rozumiem [...] jako wysoką ogólną kulturę poznawczą, połączoną z obszerną wiedzą o życiu. W tym ujęciu jest to ideał stopniowalny, który może przyświecać pojedynczym decyzjom albo całej drodze człowieka" (Pietrasiński, 2001, s. 11).

Mądrość w jej rozumieniu najpełniejszym autor przypisuje człowiekowi, którego charakteryzują łącznie:

„1) Obszerna wiedza, istotna dla rozumienia i rozstrzygania ważnych spraw życiowych, nabyta zarówno od innych i z książek, jak i w wyniku osobistych doświadczeń i refleksji.

2) Umiejętność wczesnego dostrzegania i trafnego rozwiązywania istotnych problemów życiowych, oparta na wskazanej wyżej wiedzy oraz na myśleniu wnikliwym i wybiegającym w przyszłość, ujmującym sprawy z wielu perspektyw.

3) Dojrzała osobowość, wolna od egocentryzmu i samozakłamania, otwarta na nową wiedzę, umiejąca przechodzić od myśli do zgodnego z nią czynu" (Pietrasiński, 2001, s. 15-16).

Brak mądrości zubaża człowieka, naraża go, zdaniem autora, na fatalne w skutkach decyzje i poczynania. Naraża go na głupotę.

Na kulturę poznawczą, będącą osią mądrości, składają się dyrektywy, procedury, metody - ogólnie: programy prowadzące do zachowań sprzyjających rozwiązywaniu problemów oraz tworzeniu i wykorzystywaniu nowej wiedzy. Programy obejmują z jednej strony szczegółowe, algorytmiczne przepisy działania, a z drugiej - ogólne dyrektywy i filozoficzne zalecenia dotyczące tego, jak żyć. Jedne elementy kultury poznawczej są pomocne w rozwiązywaniu wielu problemów z różnych dziedzin, pełnią więc funkcje heurystyczne, inne zaś mają zastosowanie tylko w określonej ściśle specjalności (np. w medycynie). Kulturę poznawczą dzieli więc Pietrasiński na ogólną i specjalną - poszukiwanie i kształtowanie się mądrości ma wiele wspólnego z powiększaniem i wykorzystywaniem ogólnej kultury poznawczej. Mądrość wiąże się z ogólną kulturą poznawczą, choć - jak zastrzega autor - nie sprowadza się wyłącznie do niej, ,bo ma też własną problematykę i wiedzę wyspecjalizowaną na temat - jak określa to Baltes - podstawowej pragmatyki życia" (Pietrasiński, 2001, s. 52). 
Składniki tak pojętej wysokiej kultury poznawczej są zawarte we wzorcu człowieka mądrego, którego charakteryzuje:

- Motywacja poznawcza: przyjemność czerpana z myślenia nad złożonymi problemami, dociekliwość („zgłębia sprawy, zanim podejmie decyzję”), refleksja i autorefleksja jako potrzeba i źródło satysfakcji, rozumienie a nie osądzanie, unikanie przedwczesnych sądów, poszukiwanie uzasadnień i dowodów, unikanie sądów kategorycznych, kontrolowanie i doskonalenie struktury własnej aktywności poznawczej.

- Wrażliwość na problemy: dostrzeganie złożoności spraw, dostrzeganie i stawianie problemów, widzenie nowych problemów wcześniej niż inni.

- Aktywność w sytuacjach problemowych: poszukiwanie sedna sprawy, poszukiwanie nowych informacji, badanie opinii odmiennych od własnych, ujmowanie sprawy w szerokim kontekście, rozważanie szczegółów na tle całości, unikanie pochopnych uogólnień, przewidywanie konsekwencji, także ubocznych i niezamierzonych, badanie trafności swych przewidywań.

- Osobowość: dystans do siebie, kontrola własnych emocji, unikanie myślenia życzeniowego.

- Aktywność na rzecz rozwoju osobistego: uczenie się od innych ludzi i z innych źródeł, uczenie się na własnych i cudzych błędach, rewidowanie swego dziedzictwa umysłowego, dążenie do mądrości.

Atrybuty te mogą być pomocne w stawianiu celów rozwojowych, pozostających dotąd, jak twierdzi Pietrasiński, w cieniu szkolnych przedmiotów nauczania. Kiedy jednak stawiamy mądrość za cel, porażają nas jego ogrom i nieznajomość prowadzących do tego celu dróg. Opisując jednak ten cel jako dążenie do wysokiej, ogólnej kultury poznawczej, nie rezygnujemy, zdaniem autora, z ambitnego rozwoju, przeciwnie - możemy rozpisać złożony cel na osiągalne podcele. Treść tych celów etapowych mogą wyznaczać wymienione powyżej składniki kultury poznawczej. Dążenie do mądrości może mieć wielki walor integrujący. „Nie mając takiego celu, nauczyciele coraz to nowych technik myślenia i podejmowania decyzji traktują uczniów jak magazyny, które należy wypełniać kolejnymi umiejętnościami. Podobnie traktują siebie uczniowie. Co innego, gdy celem jest mądry, coraz mądrzejszy człowiek. Wtedy fragmenty wiedzy łatwiej się łączą w zrozumiałą i lepiej zintegrowaną całość, stanowiącą istotny i atrakcyjny cel rozwoju osobistego. Cel, o który warto zabiegać" (Pietrasiński, 2001, s. 59). I dalej autor stwierdza: „powrót do pojęcia mądrości, opisywanej jako wieloelementowy system programów i nawyków poznawczych, a także wiedza życiowa - może odegrać istotną rolę w przezwyciężaniu fragmentaryzacji kształcenia umysłu i osobowości. A także zwiększyć świadomy udział jednostek w rozwoju osobistym" (Pietrasiński, 2001, s. 59-60).

Patrząc z nieco innej perspektywy, możemy uznać mądrość za cel dopełniający. I to, jak stwierdza Pietrasiński, dopełniający podwójnie: 1) jest on pomocny w realizacji innych celów ,jako swojego rodzaju instrument" ułatwiający 
współżycie z ludźmi, wychowywanie dzieci i pomoc w kluczowych decyzjach życiowych, 2) cel ten nobilituje człowieka ,jako istotę rozumną z nazwy”. Realizacja tak rozumianych celów wymaga dojrzałej „dydaktyki mądrości”, która mogłaby wspierać każdego w ,uczeniu się z księgi życia na cudzych i własnych doświadczeniach, w analizie i doskonaleniu struktury własnej aktywności poznawczej” (Pietrasiński, 2001, s. 156). Autor nie ma wątpliwości, że takiej „dydaktyki mądrości" jeszcze nie ma.

Pietrasińskiego koncepcja mądrości jako wysokiej kultury poznawczej pozwala nie tylko stawiać w miarę realne cele edukacyjne, dotyczące głównie kształcenia intelektualnego, lecz uwolnić się także od starej wizji mądrości jako niebotycznego ideału dostępnego doświadczonym przez życie starcom. Czesław Nosal (2002, s. 59), komentując książkę Pietrasińskiego, zwraca uwagę na dwa istotne wątki jego koncepcji. Pierwszy z nich koncentruje się wokół stylu myślenia i stosunku do posiadanej wiedzy, czyli na swoiście rozumianej „metodologii poznania”. „Wchodzi tu w grę poznawanie zorganizowane w taki sposób, aby nie było ono tendencyjne, aby było należycie uzasadnione (krytyczne i racjonalne), wielowariantowe, perspektywiczne i dostrzegające różnicę między wiedzą i niewiedzą. Zauważymy, że wyliczone atrybuty koncentrują się wokół poznawania obiektywnego i całościowego (holistycznego). Mądrość niczego nie gwarantuje, ale jako <nadbudowa $>$ umysłu korzystnie programuje poznawanie i bieg ludzkiego życia" - stwierdza Nosal (2002, s. 59). Nie ma przy tym znaczenia, czy poznawanie to dotyczy postaw menedżerskich, badań naukowych czy też zachowań codziennych. Drugi wątek wiąże się ze sztuką dokonywania oceny sytuacji problemowych, wyborów życiowych, wartościowania celów i strategii działania, podejmowania trafnych decyzji i kalkulowania ryzyka. Mądrość dla Nosala jest formą arcywiedzy, nadbudowanej nad inteligencją, zdolnościami, wiedzą deklaratywną, doświadczeniem osobistym i samowiedzą. Najpełniej wyraża ją otwarty styl myślenia i typ umysłowości oraz krytyczny stosunek do wiedzy. Nosal zgadza się z Pietrasińskim, iż sedno mądrości stanowi pojawienie się i nieustanny rozwój myślenia refleksyjnego. Niejako rozwinięciem tej koncepcji w kierunku laickiej teorii mądrości - mądrości bez Boga - jest inna praca Pietrasińskiego pt. Ekspansja pięknych umystów. Nowy Renesans i ożywcza autokreacja (2008).

2. Mądrość jako postawa metapoznawcza (sagacity) - teoria Roberta J. Sternberga (1990), który twierdzi, że mądrość jest sumą stylu metapoznawczego i refleksyjnej wiedzy charakteryzującej mędrca (sagacity). Ponieważ koncepcja Sternberga próbuje łączyć problematykę twórczości i zdolności poznawczych z mądrością, a taki cel przyświeca również autorom niniejszej książki, dlatego też zostanie omówiona nieco szerzej.

Tym, co odróżnia mądrość od inteligencji i twórczości, na tle których Sternberg omawia mądrość, jest właśnie wiedza mędrca, która jest czymś więcej niż tylko określonymi zdolnościami poznawczymi. Wiąże się z doświadczeniem i umiejętnością zachowania odpowiedniego dystansu do przedmiotu poznawanego, 
zawiera realną ocenę własnych możliwości poznawczych i ich ograniczeń, łączy się z silną motywacją badania granic poznania (Sternberg, 1990; Sękowski, 2000). Składnikami (aspektami) mądrości są:

1. Wiedza - rozumienie jej założeń, znaczenia i ograniczeń. Człowiek mądry potrafi analizować i wykorzystywać wiedzę, wie ponadto, czego nie wie i co ma znaczenie dla jego przedsięwzięć życiowych (Pietrasiński, 2001). Cechuje go więc metawiedza, czyli wiedza o posiadanej wiedzy. Rola wiedzy w zachowaniach inteligentnych polega na szybkim i sprawnym przypominaniu, analizowaniu i wykorzystywaniu wiadomości, w zachowaniach twórczych natomiast służy wychodzeniu poza to, co znane i dostępne.

2. Procesy - rozumienie automatyzacji procesu myślenia i jej przyczyn. Człowiek mądry stawia opór automatyzacji, rozumie przejawy automatyzacji i jej skutki w działaniach ludzkich, stara się dociec, jakie są źródła zautomatyzowanych, stereotypowych przekonań - wszystko to prowadzi do głębszego rozumienia i przewidywania zachowań ludzi. Człowiek inteligentny, zdaniem Sternberga, jest głównie nastawiony na poszukiwanie regularności i powtarzalności zjawisk, człowiek twórczy zaś na poszukiwanie nowych zastosowań.

3. Podstawowy styl poznawczy - sędziowski. Człowiek mądry nie tylko sprawnie rozwiązuje zadania w oparciu o posiadaną wiedzę, ale bada, dlaczego ludzie mówią to, co mówią i robią to, co robią. Człowieka inteligentnego cechuje na ogół styl wykonawczy, rozwiązując testy, stara się akceptować zadania i szybko je wykonać, człowiek mądry w czasie testu prawdopodobnie stawia sobie pytania, dlaczego pojawiają się problemy z jego rozwiązaniem, człowiek twórczy (styl legislacyjny) natomiast, akceptując nawet zadania, udziela odpowiedzi, które wykraczają poza przewidziane przez twórców testu. Szkoła, zdaniem Sternberga, preferuje uczniów inteligentnych o stylu wykonawczym. „Dobry uczeń to ktoś, kto wykonuje to, czego się od niego wymaga, i robi to dobrze. Uczniowie, którzy kwestionują wartości lub wyznaczone zadania bądź sami tworzą zadania różniące się od tych, których oczekuje nauczyciel, nie są prawdopodobnie doceniani przez swych nauczycieli" (Sternberg, 1990, s. 154).

4. Osobowość - człowieka mądrego cechuje tolerowanie wieloznaczności, postrzega ją jako stałą i nieuniknioną właściwość stosunków międzyludzkich. „Wieloznaczność jest czymś, co należy zrozumieć, aprobować i postrzegać jako fundamentalną cechę rzeczy" (Sternberg, 1990, s. 155). Człowiek konwencjonalnie inteligentny traktuje niejasne i wieloznaczne problemy jako coś, co trzeba przeformułować, co przeszkadza w poszukiwaniu rozwiązań i nie powinno być tolerowane - w sumie jako coś, czego trzeba się pozbyć. Człowiek twórczy uczy się tolerować wieloznaczność i mimo że nie czuje się z nią komfortowo, rozumie, że prowadzi ona do twórczego przeformułowania problemów i nowych rozwiązań.

5. Motywacja - zrozumieć, co jest znane i co to oznacza. Człowiek mądry kieruje się tym, by rozumieć głębiej założenia, strukturę i znaczenie rzeczy lub wydarzeń. Poszukuje najgłębszego znaczenia natury rzeczy nawet wtedy, gdy innym 
wydają się one banalne. Człowiek inteligentny stara się rozumieć więcej zjawisk, człowiek twórczy motywowany jest natomiast chęcią zrozumienia nowych zjawisk, stara się je widzieć w inny sposób niż reszta ludzi.

Osoba mądra, według Sternberga, ,szuka prawdy, sonduje wiedzę rozważnie i nawet z pewną satysfakcją, lubi mieć do czynienia z wieloznacznymi sytuacjami, przeciwstawia się natomiast automatyzmowi, także w sferze podejmowania decyzji w sytuacjach rozwiązywania problemów, zwłaszcza społecznych" (Sękowski, 2001, s. 103). Aby być człowiekiem mądrym, należy mieć niezbędne doświadczenia życiowe, by nabrać dystansu wobec określonych problemów. Doświadczenie życiowe sprzyja również lepszemu wglądowi w siebie, co odróżnia mądrość jako postawę metapoznawczą od innych postaw (twórczych i inteligentnych). Można więc pokusić się o konstatację, iż chcąc wychować człowieka mądrego, powinniśmy uczyć go dystansu do problemów, tolerowania wieloznaczności, analizowania stereotypów i automatyzacji w myśleniu, badania własnych założeń i ograniczeń poznawczych, dociekliwego w analizowaniu stosowanych przez siebie i innych sposobów myślenia. Powinniśmy też umieć odróżnić mądrość od inteligencji i twórczości. Inteligencja i twórczość mogą sprzyjać mądrości, ale mogą też istnieć niezależnie od niej i nie wpływać na jej rozwój. W sumie - powinniśmy budzić i wspierać postawę metapoznawczą, a więc refleksyjną świadomość własnej wiedzy, jej ograniczeń i metod wykorzystywanych do jej pogłębienia i wzbogacenia.

W ostatnich latach Sternberg rozwija koncepcję określaną akronimem WICS, który obejmuje cztery istotne dla rozwoju zdolności człowieka czynniki: mądrość (W - wisdom), inteligencję (I - intelligence), twórczość (C - creativity) oraz syntetyzowanie ( $\mathrm{S}$ - synthesized). Dopiero syntetyzowanie wszystkich trzech elementów prowadzi do rozwoju wybitnych zdolności, staje się też gwarantem harmonijnego rozwoju osobowości i osiągania dobrostanu życiowego (Sternberg, 2003; 2005).

Przedstawiłem w dużym skrócie kilka współczesnych koncepcji mądrości i ich wybrane implikacje pedagogiczne. Nie są to wszystkie stanowiska na interesujący nas temat, jakie w ostatnich latach zostały ogłoszone w środowisku naukowym. Warto wspomnieć w tym miejscu o głośnej koncepcji filozofa Józefa Marii Bocheńskiego (1992), który mądrość traktuje jako zapewnienie sobie długiego i dobrego życia i wyraźnie rozgranicza zagadnienia mądrości i problemy etyki związane z postępowaniem mądrym. Warto przywołać stanowisko zgoła przeciwne Bocheńskiemu, a mianowicie Kazimierza Szewczyka (1999) postrzegającego mądrość jako istotę etycznego działania i roli zawodowej nauczyciela, czy też Edwarda de Bono (1998; 2001), który w mądrości widzi wieloaspektowy, perspektywiczny i szeroki sposób patrzenia na świat i rozwiązywania problemów. 


\section{Zakończenie - edukacja pozytywna}

Powracam do przedstawionych we wstępie tez, w myśl których skupienie uwagi przez pedagogikę na problemach niedomagań człowieka, jego chorób i braków, może być zrównoważone przez większe zainteresowanie badaczy zagadnieniami zdrowia, zdolności, kreatywności i rozwoju mądrości. Te trzy składowe dobrostanu jednostki - twórczość, zdolności i mądrość - nie wyczerpują, rzecz jasna, całego repertuaru zasobów czy cnót rozwojowych człowieka (dodać tu można: szczęście, nadzieję i optymizm, pozytywne związki z innymi, odwagę, miłość i dobroć, wdzięczność, duchowość, poczucie sensu i in.) - mogą w moim przekonaniu być bardzo interesującym przedmiotem badań przyszłej pedagogiki pozytywnej. A oto uzasadnienie.

1. Twórczość wiąże się z działaniami człowieka, który próbuje przekraczać granice tego, co zastane i kreować, dzięki swoim zdolnościom ogólnym lub specjalnym, wartościową nowość. Mądrość pomaga w odróżnieniu nowości wartościowej od nic niewartej, wiąże się nie tylko, jak powszechnie przypuszcza się, $\mathrm{z}$ bogatą, szeroką i pogłębioną wiedzą faktograficzną, ale również z refleksją na temat granic wiedzy i samego poznania, z wątpieniem w jej ustalenia i pewniki. Chcąc rozwijać zdrową twórczość i mądrość wychowanków, powinniśmy pomóc im w zachowaniu równowagi pomiędzy wiedzą niepewną, faktograficzną i myśleniem krytycznym (refleksyjnym). Mądry i twórczy człowiek wie, co wie, i wie, czego nie wie i stan ten nie jest źródłem uporczywej nerwicy, w którą popada.

2. Mądry i twórczy człowiek nie tylko potrafi odpowiadać na trudne pytania i rozwiązywać złożone problemy, potrafi stawiać dociekliwe, odkrywcze pytania i formułować problemy tam, gdzie inni ich nie widzą. Zdolność ta nie jest prostą funkcją doświadczenia życiowego, lecz pewnego stylu funkcjonowania poznawczego, w którym myślenie pytajne odgrywa istotną rolę, może więc być nieobca nawet dzieciom.

3. Człowiek twórczy i mądry potrafi radzić sobie z dwuznacznością sytuacji i konfliktem poznawczym, cechuje go tolerancja dla dwuznaczności. Postrzega dwuznaczność jako nieodłączną cechę rozwoju wiedzy i ścierania się różnych stanowisk teoretycznych. Niejasne i dwuznaczne sytuacje traktuje jako coś, co należy aprobować i rozumieć, nie aprobuje natomiast różnorakich automatyzmów, dogmatów i kalek pojęciowych. Tolerowanie dwuznaczności służy zdrowiu psychicznemu, zwłaszcza w dzisiejszych czasach.

4. Bogatej wiedzy, wrażliwości na problemy, refleksyjności, tolerancji dla dwuznaczności, wysokiej kreatywności i wytrwałości towarzyszy w sylwetce człowieka twórczego, zdolnego i mądrego dystans w stosunku do siebie oraz swej mądrości i twórczości, rewidowanie swej wiedzy pod wpływem nowych doświadczeń i uczenia się od innych. Człowiek mądry widzi głęboko i szeroko, rozumie dużo i przewiduje konsekwencje, ujmuje sprawy w szerokim kontekście i unika 
pochopnych uogólnień, a przede wszystkim - ma dobry wgląd we własne procesy poznawcze i wie, co i jak myśli (metapoznanie).

Psychologowie pozytywni, po wykonaniu wielu podstawowych badań nad składnikami i uwarunkowaniami głównych zasobów i cnót ludzkich, powoli zwracają się w kierunku edukacji i szkół (Gilman, Scott Huebner, Furlong, eds, 2009; Seligman, 2011). Na pytanie, czy dobrostanu powinno się uczyć w szkole, odpowiadają - oczywiście, że tak! Uzasadnień dla włączenia tematyki dobrostanu i cnót do programu wychowania w szkole znajdują w dwóch niepokojących zjawiskach: „epidemii” depresji wśród młodych mieszkańców krajów zachodnich oraz śladowym wzroście lub nawet spadku poziomu szczęścia w ciągu dwóch ostatnich pokoleń w takich krajach, jak USA, Wielka Brytania, Niemcy i Rosja (Seligman, 2011, s. 117). Ale jest jeszcze trzeci, ważny, szczególnie dla autorów tej książki, powód. Wyższy poziom dobrostanu poprawia jakość uczenia się: pozytywny nastrój sprzyja rozwojowi zainteresowań, zapewnia więcej twórczego myślenia w klasie szkolnej i powoduje, iż uczniowie mają „bardziej całościowy ogląd" (tamże), czyli stają się mądrzejsi. Współtwórca psychologii pozytywnej i jej główny ideolog, Martin Seligman, pisze tak: „Uważam, że nowoczesny świat wszedł w końcu w okres, w którym możemy bardziej liczyć na sukces, stawiając większy nacisk na kreatywne myślenie czy nawet po prostu na cieszenie się życiem, a mniejszy na uczenie się na pamięć i wypełnianie poleceń. [...] poprawy dobrostanu należy uczyć w szkołach, bo wyższy dobrostan może być potencjalną odtrutką na galopujący wzrost depresji, sposobem na zwiększenie zadowolenia z życia, a także pomocą w nauce i twórczym myśleniu" (tamże, s. 118). Zgadzamy się z tym przekonaniem! A zatem najwyższa pora rozwijać pedagogikę i edukację pozytywną.

\section{Literatura}

Baltes P. B., Smith J. (1990), Toward a psychology of wisdom and its ontogenesis, [w:] Wisdom: Its nature, origins and development, R. J. Sternberg (ed.), Cambridge University Press, New York.

Baltes P. B., Gluck J., Kunzmann U. (2004), Mądrość. Jej struktura i funkcja w kierowaniu pomyślnym rozwojem w okresie całego życia, [w:] Psychologia pozytywna. Nauka o szczęściu, zdrowiu, sile i cnotach człowieka, J. Czapiński (red.), PWN, Warszawa.

Beghetto R. A., Kaufman J. C. (eds), (2010), Nurturing Creativity in the Classroom, Cambridge University Press, New York.

Birren J. E., Fisher L. M. (1990), The elements of wisdom: overview and integration, [w:] Wisdom: Its nature, origins and development, R. J. Sternberg (ed.), Cambridge University Press, New York.

Bocheński J. M. (1992), Podręcznik mądrości tego świata, Wydawnictwo PHILED, Kraków.

Colangelo N., Davis G. A. (eds), (2003), Handbook of Gifted Education, $3^{\text {th }}$ ed., Allyn and Bacon, Boston.

Czaja-Chudyba I. (2009), Jak rozwijać zdolności dziecka?, WSiP, Warszawa. 
Czapiński J. (red.), (2004), Wstęp, w: Psychologia pozytywna. Nauka o szczęściu, zdrowiu, sile $i$ cnotach człowieka, PWN, Warszawa.

Czapiński J. (red.), (2004), Psychologia pozytywna. Nauka o szczęściu, zdrowiu, sile i cnotach człowieka, PWN, Warszawa.

Carr A. (2009), Psychologia pozytywna. Nauka o szczęściu i ludzkich siłach, Zysk i S-ka Wydawnictwo, Poznań.

Clayton V. P. (1975), The meaning of wisdom to young and old in contemporary society, paper presented at the meetings of the Gerontological Society, Louisville.

Csikszentmihalyi M. (1997), Creativity. Flow and the Psychology of Discovery and Invention, Harper Perennial, New York.

Csikszentmihalyi M., Rathunde K. (1990), The psychology of wisdom: an evolutionary interpretation, [w:] Wisdom: Its nature, origins and development, Sternberg R. J. (ed.), Cambridge University Press, New York.

Csikszentmihalyi M., Rathunde K., Whalen S. (1997), Talented Teenagers. The Roots of Success and Failure, Cambridge University Press, New York.

Czerw A. (2010), Optymizm. Perspektywa psychologiczna, GWP, Gdańsk.

Davis G. A. (2006), Gifted Child, Gifted Education, Great Potential Press Inc., Scottsdale.

Davis G. A., Rimm S. B. (2004), Education of the Gifted and Talented, $5^{\text {th }}$ ed., Allyn and Bacon, Boston.

Diener E., Biswas-Diener R. (2011), Szczęście. Odkrywanie bogactwa psychicznego, Smak Słowa, Warszawa.

De Bono E. (1998), Myślenie równoległe, Oficyna Wydawnicza „Prima”, Warszawa.

De Bono E. (2001), Z nowym myśleniem w nowe tysiaclecie, Dom Wydawniczy REBIS, Poznań.

Dyrda B. (2012), Edukacyjne wspieranie rozwoju uczniów zdolnych. Studium społeczno-pedagogiczne, Wydawnictwo Akademickie „Żak”, Warszawa.

Eby J. W., Smutny J. F. (1998), Jak kształcić uzdolnienia dzieci i młodzieży, WSiP, Warszawa.

Feist G. J. (2010), The Function of Personality in Creativity: The Nature and Nurture of the Creative Personality, [w:] The Cambridge Handbook of Creativity, J. C. Kaufman, R. J. Sternberg (eds), Cambridge University Press, New York.

Fredrickson B. L. (2011), Pozytywność, Zysk i S-ka Wydawnictwo, Poznań.

Gallagher J. J. (2008), Psychology, Psychologists and Gifted Students, [w:] Giftedness in Children, S. I. Pfeiffer (ed.), Springer, Florida.

Gilman R., Scott H. E., Furlong M. J. (2009), Handbook of Positive Psychology in Schools, Routledge, New York.

Giza T. (2006), Socjopedagogiczne uwarunkowania procesu identyfikowania oraz rozwoju zdolności uczniów w szkole, Wydawnictwo Akademii Świętokrzyskiej, Kielce.

Giza T. (2009), O specjalności pedagogiki zdolności, [w:] Zdolności i twórczość jako perspektywa współczesnej edukacji, J. Łaszczyk, M. Jabłonowska (red.), Wydawnictwo Universitas Rediviva, Warszawa.

Heller K. A., Schofield N. J. (2008), Identification and Nurturing the Gifted from an International Perspective, [w:] Giftedness in Children, S. I. Pfeiffer (ed.), Springer, Florida.

Karwowski M., Gajda A. (red.), (2010), Kreatywność (nie tylko) w klasie szkolnej, Wydawnictwo APS, Warszawa.

Kaufman J. C. (2011), Kreatywność, Wydawnictwo APS, Warszawa.

Kaufman J. C., Beghetto R. A. (2004), Creativity in the Schools. A Rapidly Developing Area of Positive Psychology, [w:] Handbook of Positive Psychology in Schools, R. Gilman, H. E. Scott, M. J. Furlong (eds), Routledge, New York. 
Labouvie-Vief G. (1990), Wisdom as integrated thought: historical and developmental perspectives, [w:] Wisdom: Its nature, origins and development, R. J. Sternberg (ed.), Cambridge University Press, New York.

Landau E. (2003), Twoje dziecko jest zdolne, Instytut Wydawniczy Pax, Warszawa.

Ledzińska M., Czerniawska E. (2011), Psychologia nauczania. Ujęcie poznawcze, PWN, Warszawa. Limont W. (2010), Uczeń zdolny. Jak go rozpoznać i jak z nim pracować, GWP, Gdańsk.

Limont W. (red.), (2004), Teoria i praktyka edukacji uczniów zdolnych, Oficyna Wydawnicza „Impuls", Kraków.

Limont W., Cieślikowska J. (red.), (2005), Wybrane zagadnienia edukacji uczniów zdolnych, t. 1: Zdolności i stymulowanie ich rozwoju, Oficyna Wydawnicza „Impuls”, Kraków.

Limont W., Cieślikowska J. (red.), (2005), Wybrane zagadnienia edukacji uczniów zdolnych, t. 2: Uczeń - Nauczyciel - Edukacja, Oficyna Wydawnicza „Impuls”, Kraków.

Limont W., Dreszer J., Cieślikowska J. (red.), (2010), Osobowościowe i środowiskowe uwarunkowania rozwoju ucznia zdolnego, t. 1 i 2, Wydawnictwo UMK, Torun.

Maslow A. H. (1990), Motywacja i osobowość, IW „Pax”, Warszawa.

Meacham J. A. (1990), The loss of wisdom, [w:] Wisdom: Its nature, origins and development, R. J. Sternberg (ed.), Cambridge University Press, New York.

Moenks F., Ypenburg I. (2007), Jak rozpoznać uzdolnione dziecko. Poradnik dla rodziców, Wydawnictwo WAM, Kraków.

Nakamura J., Csikszentmihalyi M. (2004), Motywacyjne źródła kreatywności z perspektywy psychologii pozytywnej, [w:] Psychologia pozytywna. Nauka o szczęściu, zdrowiu, sile i cnotach człowieka, J. Czapiński (red.), PWN, Warszawa.

Nosal Cz. (2002), Mądremu chwała, „Charaktery”, nr 3.

O'Quin K., Derks P. (1997), Humor and Creativity: A Review of the Empirical Literature, [w:] The Creativity Research Handbook, M. A. Runco (ed.), vol. 1, Hampton Press, Cresskill.

Palka S. (2006), Metodologia. Badania. Praktyka pedagogiczna, GWP, Gdańsk.

Pfeiffer S. I. (ed.), (2008), Giftedness in Children, Springer, Florida.

Pietrasiński Z. (2000), Czy dzieci można uczyć mądrości?, [w:] Modele opieki nad dzieckiem zdolnym, M. Partyka (red.), Centrum Metodyczne Pomocy Psychologiczno-Pedagogicznej MEN, Warszawa.

Pietrasiński Z. (2001), Mądrość czyli świetne wyposażenie umystu, Wydawnictwo Naukowe SCHOLAR, Warszawa.

Pietrasiński Z. (2008), Ekspansja pięknych umysłów. Nowy Renesans i ożywcza autokreacja, Wydawnictwo CIS, Warszawa.

Piirto J. (2011), Creativity for $21^{\text {st }}$ Century Skills. How to Embed Creativity into the Curriculum, Sense Publishers, Rotterdam.

Plucker J. A., Callahan C. L. (eds), (2008), Critical Issues and Practices in Gifted Education, Prufrock Press, Waco.

Pomykało W. (1998), Mądrość, [w:] Encyklopedia psychologii, W. Szewczuk (red.), Fundacja Innowacja, Warszawa.

Postman N. (1995), Technopol. Triumf techniki nad kultura, PIW, Warszawa.

Postman N. (2001), W stronę XVIII stulecia, PIW, Warszawa.

Robinson D. N. (1990), Wisdom trough the ages, [w:] Wisdom: Its nature, origins and development, R. J. Sternberg (ed.), Cambridge University Press, New York.

Robinson A., Shore B. M., Enersen D. L. (eds), (2007), Best Practice in Gifted Education, Prufrock Press, Waco.

Salcher A. (2009), Utalentowany uczeń i jego wrogowie, Wydawnictwo Oświatowe FOSZE, Rzeszów. 
Sawyer R. K. (2012), Explaining Creativity. The Science of Human Innovation, ${ }^{\text {nd }}$ ed., Oxford University Press, New York.

Seligman M. E. P. (2004), Psychologia pozytywna, [w:] Psychologia pozytywna. Nauka o szczęściu, zdrowiu, sile i cnotach człowieka, J. Czapiński (red.), PWN, Warszawa.

Seligman M. E. P. (2005), Prawdziwe szczęście. Psychologia pozytywna a urzeczywistnienie naszych możliwości trwatego spetnienia, Media Rodzina, Poznań.

Seligman M. E. P. (2011), Petnia życia. Nowe spojrzenie na kwestię szczęścia i dobrego życia, Media Rodzina, Poznań.

Sękowski A. E. (2000), Osiagnięcia uczniów zdolnych, Towarzystwo Naukowe KUL, Lublin.

Simonton D. K. (1997), Historiometric Studies of Creative Genius, [w:] The Creativity Research Handbook, M. A. Runco (ed.), vol. 1, Hampton Press, Cresskill.

Simonton D. K. (2004), Creativity in Science. Chance, Logic, Genius and Zeitgeist, Cambridge University Press, New York.

Simonton D. K. (2010), Geniusz, Wydawnictwo APS, Warszawa.

Smutny J. F. (ed.), (1998), The Young Gifted Child. Potential and Promise, an Anthology, Hampton Press Inc., Creskill.

Starko A. J. (2010), Creativity in the Classroom. Schools of Curious Delight, $4^{\text {th }}$ ed., Lawrence Erlbaum Associates, Publishers, Mahwah, New Jersey.

Sternberg R. J. (1990), Wisdom and its relations to intelligence and creativity, [w:] Wisdom: Its nature, origins and development, R. J. Sternberg (ed.), Cambridge University Press, New York.

Sternberg R. J. (2003), Wisdom, Intelligence and Creativity Synthesized, Cambridge University Press, New York.

Sternberg R. J. (2005), The WICS Model of Giftedness, [w:] Conceptions of Giftedness, R. J. Sternberg, J. E. Davidson (eds), $2^{\text {nd }}$ ed., Cambridge University Press, New York.

Sternberg R. J. (ed.), (1990), Wisdom: Its nature, origins and development, Cambridge University Press, New York.

Sternberg R. J., Davidson J. E. (eds), (2005), Conceptions of Giftedness, $2^{\text {nd }}$ ed., Cambridge University Press, New York.

Sternberg R. J., Jarvin L., Grigorenko E. L. (2011), Explorations in Giftedness, Cambridge University Press, New York.

Szewczyk K. (1999), Wychować człowieka mądrego. Zasady etyki nauczycielskiej, Wydawnictwo Naukowe PWN, Warszawa.

Szmidt K. J. (1994), Powrót do idei mądrości, „Problem”, nr 2.

Szmidt K. J. (2002), Mądrość jako cel kształcenia. Stary problem w świetle nowych teorii, „Teraźniejszość - Człowiek - Edukacja", nr 3.

Szmidt K. J. (2006), Teoretyczne i metodyczne podstawy procesu rozwijania zdolności myślenia pytajnego, [w:] Dylematy edukacji artystycznej, t. 2, Edukacja artystyczna a potencjat twórczy czlowieka, W. Limont i J. Cieślikowska (red.), Oficyna Wydawnicza „Impuls”, Kraków.

Szmidt K. J. (2008), Wśród aspektów, wymiarów, poziomów i biegunów, czyli o próbie konceptualizacji przedmiotów badań pedagogiki twórczości, [w:] Konceptualizacje przedmiotu badań pedagogiki, K. Rubacha (red.), Oficyna Wydawnicza „Impuls”, Kraków.

Szmidt K. J. (2011), Konkurs, czyli porażka. Szkolna praktyka stymulowania zdolności uczniów, [w:] Poznać - zrozumieć - doświadczyć. Teoretyczne podstawy praktycznego ksztatcenia nauczycieli wczesnej edukacji, J. Bonar, A. Buła (red.), Oficyna Wydawnicza „Impuls”, Kraków.

Szmidt K. J. (2012), Pedagogika twórczości, nowe poszerzone wydanie, GWP, Gdańsk.

Śmigórski K. (2010), Procesy poznania utajonego u osób twórczych, Towarzystwo Naukowe KUL, Lublin. 
Thompson B., Subotnik B. (eds), (2010), Methodologies for Conducting Research on Giftedness, American Psychological Association, Washington.

Tokarz A. (2005), Dynamika procesu twórczego, Wydawnictwo UJ, Kraków.

Trzebińska E. (2008), Psychologia pozytywna, Wydawnictwo Akademickie i Profesjonalne, Warszawa.

Uszyńska-Jarmoc J. (2007), Od twórczości potencjalnej do autokreacji w szkole, Wydawnictwo Akademickie Trans Humana, Białystok.

Van Tassel-Baska J. L. (ed.), (2008), Alternative Assessments with Gifted and Talented Students, Prufrock Press, Waco.

Wiseman R. (2012), Kod szczęścia, Wydawnictwo W.A.B., Warszawa. 